\title{
INTERACTION IN THE ENGLISH CLASSROOM; AN EXPLORATORY STUDY
}

\author{
Marianella Fernández Abarca ${ }^{1}$
}

\begin{abstract}
Resumen: El objetivo de este artículo es describir el tipo de interacción que ocurrió en una clase de Inglés en un colegio público de zona rural en Costa Rica. Se presentan algunos principios teóricos relacionados con la interacción en la clase de idioma. Se utilizó el método etnográfico del paradigma cualitativo para llevar a cabo este estudio. Entre las técnicas e instrumentos utilizados están la observación no participante, el uso de un cuestionario, entrevistas, y diarios personales. Se utilizó la triangulación para validar las interpretaciones, recomendaciones, y los resultados de este estudio. Se concluye que la interacción entre profesor-estudiante y estudiante-estudiante está basada en un modelo de pregunta-respuesta en donde el profesor regula y limita la participación de los estudiantes mediante el uso de diferentes activities las cuales no estimulan un aprendizaje significativo. Los estudiantes están motivados en aprender Inglés, sin embargo existen pocos espacios para interactuar. La participación de los estudiantes es pasiva y limitada, la mayor parte del tiempo escuchan, repiten, preguntan, y responden. Los estudiantes utilizan el idioma Español para comunicarse e interactuar entre ellos. El estudio sugiere variar las actividades que se llevan a cabo en la clase para mejorar el aprendizaje de los estudiantes.
\end{abstract}

\section{Palabras clave: INTERACCIÓN/INGLÉS/ COLEGIO/ ETNOGRÁFICO/ PREGUNTA RESPUESTA}

\begin{abstract}
The main purpose of this article is to describe the interaction process that took place in an English as a Foreign Language (EFL) classroom at a public high school in the province of Alajuela, Costa Rica. This article examines some theoretical background knowledge in regards to the interaction in the language classroom. The ethnographic method, which belongs to the qualitative paradigm, was used to conduct this study. Some of the techniques and the instruments used were the non-participant observations, the use of a questionnaire, interviews, and personal diaries. Triangulation was applied in order to make valid the interpretation, results, and recommendations. The study determined that the teacher-student interaction and student-student interaction is based on a question and answer pattern. The teacher regulates and limits students ' participation through the use of different activities which do not stimulate meaningful learning. Students interact among themselves by using Spanish. The study also suggests to varying the classroom activities to enhance students learning.
\end{abstract}

Key words: INTERACTION/ ENGLISH/ HIGH SCHOOL/ ETHNOGRAFIC/ QUESTION AND ANSWER

\section{Introduction}

What do you consider of importance in order to develop a language class successfully? As a language teacher I believe it is a must to provide our students with the necessary input to let them develop their cognitive abilities to their best. I consider knowing our students and their interests an important aspect to be concerned about if we think on

\footnotetext{
1 Maestría en Educación con Mención en el Aprendizaje del Inglés, Universidad Nacional. Bachiller en la Enseñanza del Inglés de la Universidad de Costa Rica. Además, ha realizado estudios en el Instituto de Inglés como Segunda Lengua de la Universidad de Tulane, New Orleans. Está interesada en desarrollar e investigar diferentes metodologías y actividades para promover un aprendizaje significativo en la clase de Inglés como lengua extranjera. En la actualidad, trabaja como profesora de Inglés en la Universidad de Costa Rica, Sede de Occidente.

Correo electrónico: marianellafa@hotmail.com
}

Artículo recibido: 26 de abril, 2004

Aprobado: 7 de junio, 2004 
the nature of human learning. The teacher's competence in the foreign language, the methodology, techniques, and activities educators use along the classes are of dramatic importance, too. More and more aspects related to the language-learning process could be added to the endless list of key components that play an important role in our classes and it would be needed more than one article to analyze them thoroughly. However, it is a good start for language teachers to state clearly the elements they consider essential to the learning process and the ones they should devote special attention to in an attempt to provide all learners with the best conditions to stimulate a successful teaching atmosphere.

It is by combining the different elements mentioned above that teachers can limit the kind of interaction that occurs in the language classroom. When planning the language lesson, teachers should consider the possible methodology they will use, the technique they should apply as well as the specific activities they will introduce to cover a topic. Thus, a teacher might choose Total Physical Response Method by James Asher (1982), which is based on the listening and physical responding of students, to teach certain commands such as stand up, sit down, open the door, close the door, among others. Later, the teacher might consider the steps to follow as introducing one command at a time, having students listening observing the teacher, and later on, having them performed the commands, as well as giving others different commands to be performed, too. A game such as "Simon says" can be used as an activity to engage pupils in the process and to provide them with the necessary input to learn the language. Nevertheless, not all the methodologies, techniques, and activities language teachers use in the classroom promote an active participation of the learners and an interactive process to assure the completion of the language learning successfully.

\section{Literature Review}

Human interaction has been defined as a process whereby two or more people engage in reciprocal action. This action may be verbal or nonverbal (Celce-Murcia, 1987). Thus, for the purpose of teaching a language, teachers mainly focus on the verbal interaction or communicative interaction (Cummins, 1994) without separating the nonverbal interaction that is present at an early phase and which has been called the silent period (Ventriglia, 1992). In this sense, there is a certain misconception in regards to the silent period due to the fact that students are normally expected to take an active role in the language class and to show mastery of the language when they perform the commands or tests; however, if the students do not achieve the expected behavior, it can be 
misunderstood that the students are not acquiring the language. This can be one major reason to avoid paying attention only to elicited performance of students at an early stage during the language learning process but to the quality of the comprehensible input (Green, 1993) we are providing them with. This comprehensible input refers to understanding oral and written forms (Swain, 1986) of the foreign language and can be better understood by analyzing the Input ( Krashen, 1985).

Another important issue related to our discussion deals with some of the factors that benefit or affect the students' interaction in the language classroom. Among these factors we can mention the personality factors (Brown, 1980) such as the intrinsic or extrinsic motivation, self- esteem, empathy, anxiety, the extroverted and introverted students' personality types (Manchur, 1996; Green, 1993 ), sociocultural factors as students' attitudes (Champeau, 1989) as well as the culture within the classroom. In 1997, Xiao Haozhang found that one major reason why some students were able to monopolize the group discussions was related to the affective factors. While the introverted students remain quiet, the extroverted ones are likely to be talkative and learn better in this kind of discussions. Building upon the idea that " human behavior relies on reciprocal interactions among thoughts and beliefs, behaviors, and environmental factors" (Shunk \& Zimmerman, 1997, p. 35), it is the teacher's role to encourage the combination of these factors to facilitate knowledge.

The interaction that occurs in the English as a Foreign Language ( EFL) classroom or English as a Second Language ( ESL) classroom is considered of great importance during the learning process.

Merely putting students in groups isn't enough. Student interaction needs to be structured to match instructional goals. In the ESL/ EFL classroom, developing proficiency in reading, writing, listening, and speaking the target language, as well as acquiring knowledge of culture, are core instructional goals. Student interaction also needs to be structured so that the many benefits of peer-interactive approaches can come about (Ilola, Matsumoto \& Jacobs, 1989, pag. 12)

Richards (1994) has pointed out that a considerable amount of time is used in the interaction process while learning a second language. Also, he has mentioned that "a great deal of time in teaching is devoted both to interaction between the teacher and the learners, and to interaction among the learners themselves" (Richards, 1994, p.138). Teachers spend hours during each school year trying to provide the students with the necessary input for them to be able to communicate using the foreign language. However, there is a large 
number of EFL classrooms (Norman and Sprinthall, 1990) which seems to be the remarkable participation of teachers and the considerable absentness of students interventions during the class.

Interaction can be described depending on the dominant type of interaction that is taking place in the English classroom (Celce-Murcia, 1989). Thus, we need to consider the teacher-dominated, teacher-centered, and student-centered classrooms. The teacherdominated classroom is the one where the teachers spend most of the time talking, and the students participation is very limited. The teacher-centered classroom is the one where the teacher is controlling the students participation through some classroom activities and students have the chance to participate. Finally, the student-centered classroom is the one where the students can participate more actively. Besides, they can direct and develop the classroom activities by interacting among themselves and where the teacher is a facilitator of the learning process. It is easy to distinguish the kind of interaction that is taken place in our classroom and label it under one of the three kinds briefly described earlier. This simple reflective action can help us avoid the controlled dominant practice developed by the teacher to promote a quality interactive process where the students and the teacher learn together through the use of a good selection of interactive class activities (Larsen-Freeman, 1987; Ilola, Matsumoto \& Jacobs, 1989).

In the United States, researchers in the educational field have pointed out that in the last century most of the classroom activities relied on memorization by asking students to learn by heart without reflecting on the learning process. The difference between rote and meaningful learning (Ausubel, 1968) is significant and a central topic to discuss when attempting to improve the teaching process.

That is rote learning involves the mental storage of items having little or no association with existing cognitive structure... Meaningful learning, on the other hand, may be described as a process of relating and anchoring new material to relevant established entities in cognitive structures (Brown, 1980, p. 79)

A study of classroom interaction (Norman and Sprinthall, 1990) further substantiated question- and- answer as the predominant approach to teaching in this country. Research studies carried out few years ago (Norman and Sprinthall, 1990), in high school and elementary - school classrooms from kindergarten to sixth grade, demonstrated that the interaction patterns in the classrooms have not changed much in relation to the interaction that used to occur almost a century ago. The first two assertions obtained by the study of 
classroom interaction showed that teachers did most of the talking $(70 \%)$ and that their talk consisted of questions. In 1978, Carol Harmatz carried out another study about interaction in the language classroom which suggested that

Probably most language teachers are aware of the danger of talking too much and feel they are reasonable conscientious in avoiding this and striving continually to stimulate student utterances. Yet, in our investigation, teachers produced about twothirds of all utterances in class ( Baddock, B.J., \& Flagg, L.M., 1983, p. 30).

One of the very interesting aspects that affects the interaction in the English classroom is been called the teacher's interaction zone (Richards, 1994). The teacher's interaction zone is explained as the state when teachers give consciously or unconsciously more chances to some students to interact than others. Thus, the teacher's action zone is specified by those students with whom the teacher normally enters into eye contact and the ones to whom the teacher addresses questions. Also, these students usually take an active role in the language class.

\section{Ethnographic Method}

Qualitative research has provided guidelines on how to proceed (Nunan, 1997; Crabtree and Miller, 1992) through the development of a research by collecting the data and analyzing it inductively as a way to understand the situation the researcher is studying. The qualitative paradigm in order to study has different methods to develop a research. In this exploratory study, the ethnographic was has chosen the ethnographic method (Spradley, 1979; Agar, 1980), which belongs to the qualitative paradigm, to study interaction in the English as a Foreign Language classroom. Some of the techniques and the instruments used were the non-participant observations, the use of a questionnaire, interviews, and personal diaries.

According to Fetterman (1989) questionnaires are the most formal and rigid form of exchange in the interviewing activity. When a person fills out a questionnaire, there is no verbal exchange or clarification with the researcher. Thus, he has pointed out that interviews is the ethnographer's most important technique for gathering data. Interviews explain and put into a larger context what the ethnographer sees and experiences. Indeed, it requires verbal interaction and language is the commodity of discourse. 


\subsection{Research Method}

\subsubsection{Participants}

This study was carried out in one ninth graders group at an academic public high school in the province of Alajuela. This study involved a total of 33 students: 16 male and 17 female students.

In any qualitative research, the inquirer has to get access to the school and the classroom as well. Access to schools and classrooms is not something that one can take for granted (Eisner, 1991, p.171). Thus, the researcher asked the principal and the English teacher for permission to develop this study. The inquirer explained the purpose of the study and the way it was going to be achieved. This study was conducted during the month of April, 1999.

\subsubsection{Techniques and instruments}

Since the purpose of this study was to describe objectively the interaction in this EFL classroom, it was important to use reliable methods to collect the data. According to Elliot W.Eisner (1991) objectivity is to see things the way they are.

To see things the way they are is to experience or know them in their ontological state.

This is called ontological objectivity, or veridicality. In the best of all worlds, we seek veridicality in both perception and understanding (Eisner, 1991, p. 43)

The techniques applied were four: observing, interviewing, questioning, and notetaking. The instruments used to develop this study were chosen by the researcher according to the needs of the students. Some of the instruments used by the researcher were pencil, paper, questionnaire format, observation diaries, tape recorder, and a camera.

The first technique used was observation specifically -participant observation (Montero-Sieburth, 1993). The group was observed six different times. The amount of time for each observation varied from forty to eighty minutes. These observations were carried out on Tuesdays and Fridays. Special attention was paid to the interaction between the teacher - students, and students - students. At the same time, the researcher used the notetaking technique (Agar, 1980) to write down some important comments about what was happening during the class period. (See appendix A).

Later on, the questioning technique was applied to collect information from the students and the teacher about the way they interact. Six students were asked to answer a questionnaire to provide information related to the interaction process. These students were 
chosen by the inquirer according to their academic achievement in the English class. Two of these students showed a high proficiency level of the target language. Two other students showed an average mastery of the language. Finally, the last two students showed a significant need to improve their skill in the study of the foreign language. Finally, the teacher was interviewed informally in his work.

Triangulation (Eisner, 1991) was applied in order to make comparisons and assertions about the interaction in the English classroom. As it is well known, triangulation makes valid the results, interpretation, assertions, and recommendations that the inquirer will state. Thus, for the purpose of this study, the data collected through the application of the techniques was classified in patterns and divided into three different results from the observation, the questionnaire, and the interview.

\section{Results}

This section will present the data collected through the observation, questionnaire, and interview. The first part will enclose the results of the observations carried out. Then, the results of the questionnaire given to the six students will be presented in part two. The third part will contain the results of the interview of the English teacher.

\subsection{Observation results}

The observation gave the inquirer a view of the way the teacher and the students interacted. However, the researcher sometimes asked the teacher questions in regards to the class development. The questions were asked during certain moments when the teacher would approach the inquirer. At the same time, the teacher approached the inquirer to comment on the kind of activity she was developing. Among the most important outcomes derived from the observation are:

1. The English teacher called on the students sitting in the middle and the back of the classroom more often than the ones to the right and left.

2. The teacher called on the students who master the language a little more than those students who were trying to "catch up" with English.

3. Teacher - student interaction was done through questions and answers.

4. The teacher addressed the whole class or individuals to answer questions.

5. The teacher usually paid attention to the students who stood often during the class and to those who walked around the classroom.

6. The teacher did not interact with the students who were talking and misbehaving. For 
the purpose of this study, talking means exchanging information not related to the English subject.

7. Most of the students participated in the English class when the teacher called on them but few students volunteered themselves to participate.

8. All the students used Spanish to communicate with the teacher when they asked something or made a comment.

9. The teacher normally dominated the interaction within the classroom as well as the choice of activities.

10. The teacher called on students by using a group list.

\subsection{Questionnaire results}

A questionnaire (see appendix B) with 12 items was applied to six students. The inquirer took the information which was relevant according to the research question about interaction. In this case the questionnaire was applied because of the difficulty of interviewing the students. What follows are the patterns obtained as a result of the questionnaire.

\section{Patterns}

1. Students said it is important to learn English.

2. Students stated it is more important to learn how to speak English than to learn how to write it.

3. Students affirmed that the teacher usually brings games and different activities to the English class.

4. Students preferred the activities in which they could interact among themselves.

5. Students mentioned that their relationship with the teacher was appropriate in other words "normal".

6. Most of the students said that the teacher sometimes took them into account to participate.

7. Some students pointed out that their participation in the English classroom is very active. Other students affirmed their participation passive.

8. All the students wanted to participate more in the English class.

9. All the students wanted the English class to be more active that it was until that moment. 


\subsection{Teacher's interview results}

Throughout the development of this study, the teacher was asked questions related to the classroom interaction. The interview was carried out at the end of the observation period in order to wrap up with very important information. No recording was used due to the fact that the teacher did not want to be recorded.

Assertions

1. The teacher stated that the group is clearly divided into small subgroup which influences negatively the way students interact and the way they learn. In other words, students whose academic achievement is excellent interact among themselves, giving few or none opportunities to exchange information and interact with other students whose academic achievement is not that good.

2. The teacher consciously interacted more often with those students who sit in the back of the classroom as well as the students sitting at the far right and left of the classroom.

3. The teacher affirmed that the students who sit in the back try to avoid participation. That is why he calls on them very often.

4. The teacher asked students questions to check if they understood what had been taught.

5. The teacher brought different interactive activities to have her students interacting among themselves. Some of these activities were different games, puzzles, songs, and videos.

6. Some activities required students to interact among themselves. Some others required them to interact with the teacher. Also, students had to work on a task individually and then shared what they previously discussed with the rest of the class.

7. The teacher mentioned that her relationship with the students is good.

8. For the most part, the interaction that took place in the English class is between the teacher and the students. It sometimes occurred among students only.

9. The teacher asserted that she had to direct the English class by asking many questions in order to check if the students were understanding what was being taught.

10. The teacher said that using a lot of activities in the English classroom would take too much time and she needed to cover some units every term.

11. The teacher liked to interact with all the students, but sometimes she paid no attention to the students who are misbehaving.

12. The teacher used the group list to call on the students as a way to interact with them. 


\section{Analysis of the results}

The analysis states clear information that can contribute to the enrichment of the teaching and learning process in English language classrooms. The patterns of analysis shown below are based on all the information gathered through the observations, the questionnaires, the interview, and note-taking.

Patterns:

1. The teacher interacted with most of the groups by asking and answering questions. She also used games, conversations, dialogues, puzzles, and songs. However, she hindered use of a wide variety of activities because of time factors.

2. The students were motivated to learn English because they believed it was very important for their lives. Also, they considered the teacher provided interesting activities that involve them in the learning process.

3. The students interacted with the teacher individually; however, they sometimes had the chance to interact among themselves.

4. The teacher's action zone included the back seats as well as the right and left row seats.

\subsection{Recommendations}

This study describes the interaction that occurred in a group of ninth graders at a public high school. Some reasonable implications of the findings in this study for all EFL teachers in Costa Rica are offered.

1. It is necessary to provide opportunities to interact with the teacher and students. If teachers want to avoid a teacher-dominated classroom, they have to reorganize the activities developed in the classroom. It would be convenient to orient the language classroom to cooperative learning groups (Jeffrey, 1984; Richard-Amato, 1988; Jacobs \& Hall, 1994), collaborative groups (Damon \& Phelps, 1988), and peer interactive learning activities. Throughout the use of activities such as brainstorming and problem-solving (Al-Arishi, 1994), role play, simulations (Hyland, 1993), and discussion, among others, we will motivate students to learn in a more engaging way. This kind of activities can provoke a very positive attitude towards language learning since they resemble real life events and stimulate critical thinking skills. However, it is the teacher's role determine when and how to use these activities. 
Another useful technique to promote active students' participation is to learn all of the students` names (Celci-Murcia, 1989). This may be a very difficult practice to follow if we take into account there are around 30 to 40 students in each classroom at public high schools in Costa Rica although it is not an impossible task to achieve.

2. This study highlights the importance of reflecting upon the teacher's role and students ' role in the language classroom. While teachers should be facilitators of experiences and knowledge, students should be active constructors of their knowledge. The idea is to reflect upon what Pablo Freire (1970) once described as banking and libertarian education.

Banking education involves the act of depositing. The student is an empty depository and the teacher is the depositor. The students receive, memorize, and repeat. There is no real communication. The role of the student is a passive one, a sort of disengaged brain. On the other hand, in libertarian education the teacher and the students are partners (Richard-Amato, 1988, p. 33)

3. Teachers should avoid the question and answer pattern as a way of checking students' progress. Rather, they should look for some performance assessment techniques ( Rudner \& Boston, 1994) such as group projects, oral presentations, constructed-response questions, demonstrations, simulations, debates, among others, that can be used to encourage students construct meaningful learning experiences while applying critical thinking skills. Asking and answering questions limits interaction in the language classroom since there is no further commentary about the topic. Having students asking and answering questions does not assure they are learning or acquiring the language for they are following a routine and still do not understand the use of the grammatical structure.

4. Time is an essential part of the learning process all teachers have to learn to deal with. Most of the activities that involve active participation among students use up a lot of time. Thus, language teachers need to reorganize the classroom activities so that they make a good use of time. Little by little, teachers can include activities such as role plays, information gaps (Larsen-Freeman, 1987), cooperative learning groups, small group, and pair work. These activities can be used not only to present a topic but also to assess students' progress. 
5. Students must be persuaded to interact positively and effectively in the language classroom. As seen in this study, most of the students felt motivated about learning English which is one major advantage for them to acquire new structures. "It is recognized that students' feelings and attitudes can promote or deter language learning. As a result, teachers attempt to create the kind of environment in which the possibility of negative affect arising is minimized" (Larsen-Freeman, 1987).

6. It is essential to remind teachers to make error-corrections (Hahn, 1987; Klassen, 1991) in a very careful way so that the students feel comfortable at the remarks made by the teacher and not frustrated at the attempt to use the target language. It seems sometimes that students are afraid of making errors and so they do not risk to participate.

7. Language teachers must reflect upon improving their knowledge of the all aspects related to the teaching of English (Prodomou, 1991). To accomplish this, teachers should work together to gain hints from colleagues to solve problems and plan different research projects to study learners and attitudes.

\section{Conclusion}

As language teachers, we usually center our attention toward providing explanations while the students remain in silence. During a language class, many language teachers might have felt that they spent a considerable amount of time doing the talking and encouraging the students to participate rather than listening to students and helping them to cope with their weaknesses.

Teachers need now to be more conscious of the usefulness of applying and varying different teaching methodologies, techniques, and activities to promote students' active participation. Based on recent studies (Tsui, 2001) on students' interaction learners' participation increases when pair work and group work tasks were assigned. This kind of activities help students exchange information to obtain comprehensible input while they are engaged in constructing meaningful experiences to achieve academic success. There are many activities teachers can use to lower students' affective filter (Krashen, 1981) and help them learn. Some of these activities were mentioned in this study, but it is the educator who, based on the students' abilities, needs, and interests, will choose the ones that apply to students' situation.

Science helps us to be informed in contributing to our understanding of learning and of 
language, but it is the artistic aspect of teaching that requires us to uniquely interpret and apply the scientific information in making choices for any given situation (LarsenFreeman, 1987, p. 9)

Although this study determined serious deficiencies in the language classroom which refer to the teacher-dominated classroom, question-answer interaction patterns as well as the use of a few interactive activities to foster a non-threatening environment, positive teacher's attitude can help diminish the weakness found. A reflective teaching approach (Arnold, 1991; Al-Arishi, 1994) would give language teachers hints to overcome the everyday problematic situations they deal with in the classroom. Once teachers are conscious of the way they are carrying their teaching, they will be able to make the necessary turns to bring the ship back to shore.

\section{References}

Agar, M.H. (1980). The professional stranger: an informal introduction to ethnography. Florida, United States: Academic Press, Inc.

Al-Arishi, A.Y. (1994). Practical ways to promote reflection in the ESL/EFL classroom. English Teaching Forum. 32 (2):2-6.

Alfaro, G. (1994). El educador como aprendiz. Revista Educación. 18 (1): 7-15.

Arnold, J. (1991). Reflections on language learning and teaching: an interview with Wilga Rivers. English Teaching Forum. 29. (1):2-5.

Asher, J. (1982). Learning another language through actions: the complete teacher's guidebook. California, United States: Sky Oaks Production, Inc.

Ausubel, D.A. (1968). Educational psychology: a cognitive view. New York, United States: Holt, Rinehart \& Winston.

Baddock, B.J., \& Flagg, L.M. (1983). Interaction in advanced language classrooms. English Teaching Forum. 21(2): 30-34.

Bogdan, R., \& Biklen, S. (1982). Qualitative research for education: an introduction to theory and methods. Boston, United States: Allyn \& Bacon Inc.

Champeau, C. (1989). The role of the teacher in today's language classroom. English Teaching Forum. 27 (3): 2-5.

Crabtree, B., \& Miller, W. (1992). Doing qualitative research. U.S.A.: Sage publications, Inc. 
Cummins, J. (1994). The acquisition of English as a second language. In kids Come in All languages: reading instruction fro ESL students. Delaware, United States: International Reading Association Inc.

Damon, W., \& Dressler, W. (1988). Critical distinctions between three methods of peer education. New Orleans, United States: AERA.

Eisner, E.W. (1991). The enlightened eye: qualitative inquiry and the enhancement of education practice. New York, United States: Mac Millan.

Fetterman, D. (1989). Ethnography step by step. London: Sage Publications.

Freire, P. (1970). Pedagogía del oprimido. Madrid, España: Ed. Siglo XXI.

Green, C.D. (1993). Learner drives in second-language acquisition. English Teaching Forum. 31 (1): 2-5

Hahn, C. (1987). Trial and error. English Teaching Forum. 25 (3): 8-11.

Harmatz, C. (1978). Interaction in the language classroom. English Teaching Forum. 16. (4).

Haozhang, X. (1997). Tape recorders, role-plays, and turn-taking in large EFL listening and speaking classes. English Teaching Forum. 35 (3): 33-36.

Hyland, K. (1993). Language-learning simulations: a practical guide. English Teaching Forum. 31.(4) 16-20.

Ilola, L.M., Matsumoto, K., \& Jacobs, G. (1989). Structuring student interaction to promote learning. English Teaching Forum. 27 (3): 12-16

Jacobs, G., \& Hall, S. (1994). Implementing cooperative learning. English Teaching Forum. 32. (4): 2-5.

Jeffrey, S. G. (1984). Using learning styles to construct cooperative learning groups and develop leadership skills. In Teaching and Change. 1(3): 295-309.

Klassen, J. (1991). Using student errors for teaching. English Teaching Forum. 29 (1): 1012.

Krashen, S.D. (1981). Bilingual education and second language acquisition theory. In Schooling and language minority students: a theoretical framework. Los Angeles, United States: ---- .

Krashen, S.D. (1985). The input hypothesis: Issues and applications. London: Longman.

Larsen-Freeman, D. (1987) From unity to diversity: twenty-five years of language- teaching methodology. English Teaching Forum. 25 (4): 2-10

Lester, J.D. (1993). Writing research papers: A complete guide. New York, United States: Harper Collins. 
Manchur, C. (1996). A teacher's guide to cognitive type theory and learning style. Virginia, United States: ASCD.

Montero-Sieburth, M. (1993). Corrientes, enfoques e influencias de la investigación qualitative para Latinoamérica. La Educación. 3 (116):491-517.

Nunan, D. (1997). Research methods in language learning. New York, United States: Cambridge University Press.

Prodomou, L. (1991). The good language teacher. English Teaching Forum. 29 (2): 2-7.

Richard-Amato, P. A. (1988). Making it Happen: interaction in the second language classroom: From theory to practice. New York, United States: Longman.

Richards, J. C. (1994). Reflective teaching in Second language classrooms. New York, United States: Cambridge University Press.

Seidman, I.E. (1991). Interviewing as qualitative research. New York and London: Teachers College Press, Columbia University.

Shunk, D.H., \& Zimmerman, B.J. (1997). Developing self-efficacious readers and writers: the role of social and self-regulatory processes. In Reading engagement: motivating readers through integrated instruction. Delaware, United States: International Reading Association Inc.

Spradley, J. (1979). The ethnographic interview. U.S.A.: Holt, Rinehart and Winston.

Sprinthall, N.A., \& Sprinthall, R.C. (1990). Educational psychology: a developmental approach. United States: McGraw-Hill.

Sprinthall, R.C., Schmutte G.T., \& Sirois L. (1991). Understanding educational research. New Jersey, United States: Prentice Hall, Englewood Gliffs.

Swain, M. (1986). Communicative competence: Some roles of comprehensible input and comprehensible output in its development. In Bilingualism in education: Aspects of theory, research and practice. London: Longman.

Tsui, A.B., (2001). Classroom interaction. In The Cambridge Guide to Teaching English to Speakers of Other Languages. United Kingdom: Cambridge University Press.

Wax, R. (1993). Doing fieldwork: Warnings and advice. Chicago, United States: The University of Chicago Press. 


\section{APPENDIX A}

\section{First observation}

Time: $8: 25$ to $9: 45$ am.

Date: Friday, April 9, 1999.

Events:

1. The teacher greeted the students and wrote the date on the board.

2. The teacher called the roll and at the same time asked some students to read the date. After asking six students what date it was, the teacher continued calling the roll without asking any more students.

3. The teacher started to explain in English how to use frequency adverbs. He drew a picture on the board and wrote the basic steps to make questions by using these adverbs; for example, he wrote:

1. What + do/does + sub $+a d v .+$ do + comp?

2. Then, he asked the students questions using that structure.

3. The teacher asked the students to open their textbooks. Students were asked to answer orally some questions based on the information presented in the page they were studying. Also, the teacher called on two students, one student asked the question and the other student answered it.

4. Students were asked to open their workbooks to page 4 and to individually complete an exercise from that page. Some students did not have the workbook so they moved next to other classmates.

5. Three students from another group came to invite the class to a coming dance. Most of the students paid attention to these students`invitation.

6. During the first five minutes of answering the written exercise, some students were asking the teacher about questions they had. Some other students were distracted and some were just talking.

7. A student from another group got sick so the English teacher was asked to give the student a ride home. At that moment, the teacher asked the observer to continue teaching the class.

10. The observer read aloud the first dialogue of the textbook and students followed her silently. Then the observer asked one student to read some parts of the dialogue. Later on, the observer called on two students and they tried to read it. 


\section{Second observation}

Time: 9:05 to 9:45 am.

Date: Tuesday, April 13, 1999.

Events:

1. The teacher greeted the students.

2. The teacher wrote the date on the board and started to call the roll.

3. The teacher asked the students to open their books to page four.

4. The teacher read the dialogue once.

5. The teacher asked one student to read the dialogue along with him.

6. Two students were asked to read it. The students read it but with some difficulty.

7. Many students asked the teacher about some words they did not understand in the dialogue. Students used Spanish to ask.

8. The teacher asked the students some questions related to the dialogue and using frequency adverbs.

9. The teacher asked students some personal questions by using frequency adverbs such as "how often do you go out?, how often do you exercise?".

10. As a homework assignment, the teacher asked the students to study the frequency adverbs which appear on page five of the textbook.

\section{Third Observation}

Time: $8: 25$ to $9: 45$ am.

Date: Friday, April 16, 1999.

Events:

1. The teacher greeted the students and called the roll.

2. The teacher wrote the date on the board and asked some students to read it. A student did not want to read it so the teacher took her to the front and helped her to read it.

3. The teacher talked for few minutes about the coming English test,

4. On the board, the teacher wrote a question that students can follow as a way of asking a question and answering it; for example, he wrote: Question: How much + time/ money +do +you +spend +in candies/ in the shower? Answer: Not very much / 
Too much / Nothing/ A great deal

5. By using the above grammar construction, the teacher asked students some questions and the students had to answer using one of the four possible answers.

6. The students were asked to open their books to page 4 of the textbooks. There is a Grammar section on that page so students were asked to read it. Some students has some questions and they asked the teacher to explain them. These students used Spanish in order to express themselves.

7. The teacher wrote some phrases on the board and students had to write questions and answers by using the information given by the teacher. Some of the phrases that the teacher wrote were: 1) in jewels, b) practicing sports, c) in snacks, d) at home, e) in CD`s, f) studying.

8. After some minutes, the teacher asked a student to ask a question to a classmate. The teacher took the list of the group and made sure that he was calling on some students who had not participated yet. Most of the students took part in this activity even when they were making mistakes.

9. The teacher called on one student and asked her to leave the classroom. The teacher wrote an observation form and the student had to leave the classroom. This student was the one who did not want to read the date at the beginning of the class.

10. The students asked the teacher questions in Spanish about what they did not understand.

\section{Fourth Observation}

Time: 9:05 to 9:45 am.

Date: Tuesday, April 20, 1999.

Events:

1. The teacher wrote the date on the board and called the roll.

2. The teacher started to explain the new topic: Sports.

3. The teacher spent some time talking about sports such as soccer, volleyball, swimming, baseball, and tennis.

4. The teacher talked and used mimicking to refer to the special equipment used to practice these sports.

5. The teacher wrote on the board the names of some sports and some equipment. 
6. Some students asked the teacher about the meaning of some words as the teacher read an article. These students used Spanish to be understood.

7. By using gestures or by giving some examples, the teacher helped the students understand the meaning of the words asked by the students.

8. The teacher asked the students to work on an assignment that had to be turned in.

\section{Fifth Observation}

Time: 9:05 to 9:45 am.

Date: Tuesday, April 27, 1999.

Events:

1. The teacher greeted the students.

2. The teacher wrote the date on the board and asked two students to read it .

3. The teacher called the roll and collected the homework assignment. In groups, the students were asked to bring and make playing cards. Some cards contained drawings of the equipment used to play different sports. Some other cards contained the name of the sports.

4. Students were asked to open their workbooks and to complete a written exercise related to sports.

5. Some students did not bring their workbooks so they sat by a classmate.

6. While the students were working on the exercise, they asked the teacher questions. Most of the time, the students used Spanish to ask the teacher questions about something they did not know or understand.

7. Orally the teacher asked some students to answer the exercise. When a student could not answer a question, the teacher called on another student.

8. Right before the end of the class, the teacher reminded students that the next lesson they will be given the playing cards back and will continue working on sports.

\section{Sixth Observation}

Time: 8:25to 9:45 am.

Date: Friday, April 30, 1999.

Events:

1. The teacher greeted the students. 
2. The teacher called the roll and wrote the date on the board.

3. The teacher asked students to form groups to play with the playing cards they already made.

4. Students made ten groups. Some groups were formed by two, three or four students.

5. The teacher gave the students the playing cards back.

6. Some students played for a while and then started to talk.

7. Some students played and asked the teacher whenever they did not understand.

8. While students were playing, some of them approached the observer to ask her the meaning of some words. They used Spanish most of the time while playing.

9. Two students were not present.

10. During the activity, two other students asked the teacher for permission to leave the classroom because they had an emergency.

11. While students were working in groups, the observer could ask the teacher some questions related to the qualitative research. 


\section{Appendix B}

\section{Cuestionario}

Indicaciones:

Estimado (a) estudiante: el presente instrumento pretende recolectar información valiosa sobre las diferentes interacciones que se llevan a cabo durante la clase de Inglés. Por favor, sírvase contestar en forma clara las preguntas que se presentarán a continuación, aportando cualquier dato que usted considere importante. Además, se le recuerda que la información que usted brinde será utilizada de manera totalmente confidencial.

I- Información sobre el estudiante.

Por favor marque en el espacio apropiado o complete la información que se solicita.

1. Sexo

masculino

femenino

2. Edad

14 años

16 años

15 años 17 años

3. Ha cursado sus estudios de secundaria en instituciones públicas privadas

4. Se encuentra cursando el noveno año por primera vez segunda vez

5. ¿Ha tenido contacto con el idioma Inglés fuera de la clase? Sí No

Información general sobre su participación en la clase de Inglés.

1. El aprender Inglés es para usted:

Muy importante Importante

Poco importante

Nada importante 
¿Por qué? Justifique su respuesta

2. El próximo año escogeré como idioma extranjero:

Francés

Inglés

¿Por qué? Justifique su respuesta

3. ¿Qué es lo que más le importa o le gusta aprender en la clase de Inglés? Enumere del 1 al 4 ( uno es el más importante y cuatro el menos importante) su preferencia. comprensión de lectura comprensión de escucha hablar en Inglés escribir en Inglés

¿Por qué? Justifique su respuesta

4. El profesor de Inglés proporciona activities para aprender lo que a usted le gusta.

siempre
a menudo
de vez en cuando
nunca

¿Por qué? Justifique su respuesta

5. ¿Qué tipo de activities se llevan a cabo durante las clases de Inglés?

6. ¿Cuáles activities le gusta más que se lleven a cabo durante la clase de Inglés? ¿ Por qué? Justifique su respuesta. 
7. ¿Cómo es la relación alumno- profesor entre usted y su profesor de Inglés?

Muy buena

Buena

Regular

Mala

¿Por qué? Justifique su respuesta

8. Me gusta participar en la clase de Inglés ...

siempre

a menudo

de vez en cuando

nunca

¿Por qué? Justifique su respuesta

9. ¿ Ha sentido que el profesor lo toma en cuenta para participar en la clase?

siempre

a menudo

de vez en cuando

nunca

¿Por qué? Justifique su respuesta

10. En la clase de Inglés soy un estudiante

Muy activo

Activo

Poco activo

Nada activo 
¿Por qué? Justifique su respuesta

11. En la clase de Inglés me gustaría ser un estudiante ...

Muy activo

Activo

Poco activo

Nada activo

¿Por qué? Justifique su respuesta

12. ¿Cómo le gustaría que fuera su participación en la clase de Inglés? 